\title{
Use of Environmental Material in Learning Indonesian at School
}

\author{
Yenesa Enjela/19016065 \\ Universitas Negeri Padang-FBS \\ yenesaenjela11@gmail.com
}

A very important element in influencing human life is the environment. The environment is a place where humans depend on life to meet their needs in the form of material, physical, and spiritual. In addition, the environment is also a place for children to get a positive attitude. The large role of the environment in life, makes children often do not realize that the little things they do can have an impact on the environment and surroundings. For example, flooding and deforestation. Floods occur due to a person's ignorance of the environment who often throws garbage in an inappropriate place. Then, illegal logging has an impact on nature being damaged. This is, due to human selfishness, resulting in a series of problems. If not addressed, it will have a negative impact on nature, climate, pollution, and the economy (Ramadhan et al., 2019). Related to this problem, it is important for teachers and parents to provide lessons to children about what needs to be done so that the environment is just right. In addition, other efforts such as expanding knowledge and optimizing a proper environmental education system will also raise students' awareness of the importance of protecting the environment (Sukma et al., 2020).

Environmental-themed creative learning will increase student enthusiasm (Sukma, 2007). Because, students will gain a lot of knowledge about how to protect the environment. Through knowledge, students can distinguish what is good and vice versa. So, indirectly students' attitudes will lead to positive actions such as not throwing garbage into the river (Ramadhan et al., 2019). Furthermore, Putri and Syahrul (2019) said that environmental learning needs to be optimized with effective reading skills, so that students will be able to master the material well.

The success of a learning depends on the criticality of the teacher in using the methods and teaching techniques. In line with this, Karatekir (in Sukma et al, 2020) said that by teaching material about the environment, students were able to understand the examples they encountered around them. Meanwhile, teachers and students both have an important role in learning. Without this reciprocal relationship, the achievement of learning objectives will 
not be met. The right learning model is able to foster students' creativity in the Indonesian language learning process (Amalia et al., 2018). So, to increase learning motivation and develop critical thinking, media that is appropriate to the environment around students is needed.

Previously, the minister of education of the republic of Indonesia, said that the process of implementing learning should be determined according to the characteristics of students and subjects, because environment-based learning can run smoothly, if students can work together with teachers in achieving learning goals (Marisya \& Sukma, 2020). Then, Sukma (2005) said that the factor that also supports the success of learning is language. Through good language, it will help students interact and socialize easily with the surrounding environment. In addition, Guci et al., (2018) revealed that compatibility and harmony between living organisms need to be maintained.

The success of students mastering learning is due to a strong learning motivation (Zulhafizh et al, 2013). The environment is one of the factors that can be used as motivation for students to continue to explore knowledge. In addition, the teacher's attitudes and actions related to the environment will be an example, because students consider teachers to be future role models. Oleh sebab itu, perilaku siswa dipengaruhi oleh perilaku guru (Sukma et al, 2020). In addition, teachers can choose the right learning model and approach, so that students will more easily understand the learning material (Agusti et al, 2021).

Previously, the author had distributed questionnaires to students and students. The acquisition of respondents was dominated by students. Of the 30 total respondents, $76.6 \%$ were women, $23.3 \%$ were men. The results of the percentage of the questionnaire conducted through the google form can be seen as follows. The first statement, environmental damage causes a series of natural problems such as climate and economy, resulting in an imbalance in the environment. $41.7 \%$ stated strongly agree, $55.6 \%$ agreed, $2.8 \%$ disagreed, and $0 \%$ disagreed. The second statement, efforts that can be made to keep the environment beautiful, namely not using water excessively. $27.8 \%$ strongly agree, $61.1 \%$ agree, $8.3 \%$ disagree, and $2.8 \%$ disagree. The third statement, students' sense of responsibility about the importance of protecting the environment needs to be applied in the school environment. $66.7 \%$ strongly agree, $33.3 \%$ agree, $0 \%$ disagree, and $0 \%$ disagree. The fourth statement, not only in the school environment, at home also a healthy living culture can be applied in the daily life of students, so that children will get used to always maintaining personal hygiene. $69.4 \%$ 
strongly agree, $30.6 \%$ agree, $0 \%$ disagree, and $0 \%$ disagree. The fifth statement, environmental-based learning aims to make students excel in protecting the environment. $33.3 \%$ strongly agree, $58.3 \%$ agree, $5.6 \%$ disagree, and $2.8 \%$ disagree. The sixth statement, community activities that are often careless cause many environmental problems. $33.3 \%$ strongly agree, $61.1 \%$ agree, 5.6\% disagree, $0 \%$ disagree. The seventh statement, environmental cleanliness can reflect our clean personality. $61.1 \%$ strongly agree, $38.9 \%$ agree, $0 \%$ disagree, and $0 \%$ disagree. The eighth statement, the environment and self that are maintained allow us to always be healthy and avoid diseases, such as skin diseases. $44.4 \%$ strongly agree, $55.6 \%$ agree, $0 \%$ disagree, and $0 \%$ disagree. The ninth statement, maintaining a clean environment is a difficult thing to do. $8.3 \%$ strongly agree, $27.8 \%$ agree, $30.6 \%$ disagree, and $33.3 \%$ disagree. The tenth statement, maintaining a clean environment can start from small things, but sometimes it is very difficult to do. $19.4 \%$ strongly agree, $52.8 \%$ agree, $16.1 \%$ disagree, and $11.1 \%$ disagree.

From the results of the research above, the authors can conclude that environmental material is very important in learning Indonesian at school. Environmental-based learning makes it easier for students to master the material, because the material mastered is related to daily activities. In addition, respondents realized that environmental-based learning could improve student achievement in protecting the environment. It is proven that environmental materials are very effective to be applied in Indonesian language learning. 


\section{LITERATURE}

Agusti, R., Syahrul, R., \& Hakim, R. (2021). Improvement of Narrative Writing Ability Based on Constructivism Approach in Elementary School. Journal of Basicedu, 5(2), 930-942.

Amalia, F., Syahrul, R., \& Arief, E. (2018). The Effect of Discovery Learning Model Assisted by Audiovisual Media on the Skills of Writing Exposition Texts for Eighth Grade Students of SMP Negeri 31 Padang. Journal of Indonesian Language and Literature Education, 7(1), 125-132.

Guci, I., Syahrul, R., \& Nursaid, N. (2018). Correlation of Vocabulary Mastery in the Environmental Sector with Writing Argumentative Essays About the Environment. Journal of Indonesian Language and Literature Education, 5(2), 169-174.

Marisya, A., \& Sukma, E. (2020). The Concept of the Discovery Learning Model in Integrated Thematic Learning in Elementary Schools According to the Experts' View. Journal of Education Tambusai, 4(3), 2189-2198.

Putri, Diana and Syahrul R. (2019). The Correlation of Reading Comprehension Skills and Writing Skills in Reports on Observation Results of Class VII Students of SMP Negeri 4 Pariaman. Journal of Indonesian Language and Literature Education, 8(1), series A 62-69.

Ramadhan, S., Sukma, E., \& Indriyani, V. (2019). Environmental Education and Disaster Mitigation Through Language Learning. IOP Conference Series: Earth and Environmental Science, 314.

Sukma, E., Ramadhan, S., \& Indriyani, V. (2020). Integration Of Environmental Education In Elementary Schools. In Journal Of Physics: Conference Series (Vol. 1481, No. 1, P. 012136). IOP Publishing.

Sukma, E. (2007). Improving the Poetry Writing Ability of Fifth Grade Students of SD Negeri Sumbersari III Malang with Mind Mapping Strategy. Diction, 14(1), 38-48.

Sukma, E. (2005). Application of Communicative Approach in Learning Indonesian Language Structure in Elementary School. Diction, 12(1).

Zulhafizh, Atmazaki, dan Syahrul Ramadhan. (2013). Kontribusi Sikap dan Motivasi Belajar Siswa terhadap Hasil Belajar Bahasa Indonesia. Jurnal Bahasa, Sastra dan Pembelajaran, Volume 1, Nomor 2, Halaman 13-28. 